\title{
MIDA TEEB TEGEMA-VERB HOIDJAKEELES
}

\author{
Reili Argus \\ Tallinna Ülikool
}

Kokkuvõte. Esimese keele omandamist mõjutab lapsele suunatud keel ehk hoidjakeel, mis pakub lapsele loomuliku keele sellise statistilise struktuuri, kus tõuseb esile mingi keelesüsteemi osa kõige sagedasem, üldisem, prototüüpsem, kesksem ning kõige lihtsam element. Hoidjakeeles esineb teistest verbidest sagedamini verbi tegema. Selle verbi ühendite hulk ja laad muutub lapse kasvades. Üldjoontes võib tegema-verbi tugiverbikonstruktsioonid lapsele suunatud kõnes jaotada kolme suuremasse rühma: kõige enam esineb selliseid ühendeid, kus tegemaverbiga esineb koos mõni onomatopoeetiline sõna; tegema-verbi ja adverbi või adjektiivi ühendeid, millega rõhutatakse teelisust, leidub mõnevõrra vähem ning umbes neljandiku moodustavad tegema-verbi ja noomeni ühendid. Püsiühendite ja rutiniseerunud mallide suur hulk (moodustavad lapsele suunatud kõnes tegema-verbi konstruktsioonidest peaaegu poole) annab alust oletada, et lapsega kõneleja eelistab kasutada n-ö valmis kujul keeletükke. Kuigi tegema-verbil on oma roll nii leksika kui ka süntaksi omandamises, ilmneb tema olulisus kõige selgemalt vormimoodustuse omandamise kontekstis: just sellest verbist esineb lapsele suunatud kõnes kõige enam eri vorme ning just see on üks kahest varakult omandatud vormimoodustusega verbe ka lapse kõnes.

Märksõnad: esimese keele omandamine, tugiverbi konstruktsioonid, lapsele suunatud kõne, hoidjakeel, lastekeel

\section{Tugiverbikonstruktsioonide rollist hoidjakeeles ja lastekeeles}

Verbimorfoloogia on lastekeeleuuringute keskpunktis olnud aastakümneid, alates juba Roger Browni 1973. aasta uurimusest (Brown 1973). Siiani on aga vähe vaadeldud seda, kuidas mõju- 
tab verbimorfoloogia omandamist lastele suunatud kõne. Lapsele suunatud kõnet ehk hoidjakeelt eristavad täiskasvanule suunatud kõnest kindlad tunnused. Eesti keele omandamise kontekstis on lühidalt kirjeldatud noomeni muutemorfoloogia omandamisega seotud erijooni, nagu deminutiivtuletus muuttüübinihke teenistuses ning teatud muuttüüpide ja morfofonoloogiliste mallide eelistamine (Argus 2008: 37-38, 126), verbimorfoloogiat ja verbikeskseid konstruktsioone eesti hoidjakeeles seni põhjalikumalt uuritud ei ole.

Konstruktsioonigrammatika keskne seisukoht on, et kui laps kuuleb mingit verbi väga sageli mingis kindlas süntaktilises ümbruses, siis aitab see tal verbi tähenduse viia kokku mingi kindla süntaktilise malliga. Goldberg jt on leidnud, et emad kasutavadki mingeid kindlaid verbe esialgu ainult mingis kindlas lausemallis. (Goldberg jt 2004) Seega on verbikesksete konstruktsioonide semantika ja süntaksi arengu taga (ehk oskuse taga siduda mingi kindla verbi semantika mingi kindla malli ehk süntaksiga, Sethuraman ja Goodman 2004: 60) hoidjakeel, sest väidetavalt järgivad lapsed enne kolmeaastaseks saamist väga täpselt hoidjakeeles esinevaid kindla verbiga kasutatavaid lausemalle (Cameron-Faulkner jt 2003 ning Theakston jt 2001). Lisaks on leitud, et teatud kindlat tüüpi konstruktsioonides esinevad esialgu ainult mingid kindlad verbid. Sethuraman ja Goodman väidavad, et laste vanuses 20 ja 28 elukuud kasutavad vanemad lastele suunatud kõnes sellistes transitiivse verbi konstruktsioonides, kus on väljendatud mingile objektile otseselt suunatud tegevus, kõige sagedamini verbi tegema (inglise verb do) (Sethuraman ja Goodman 2004: 63) ${ }^{1}$. Laste varaste lausemallide põhjaks arvataksegi olevat teatud kindlate verbide (tegema-verb seal hulgas) positsioonilised mallid (Lieven jt 1997: 208).

Tomasello ei ole aga päris nõus Sethuramani ja Goldbergi väitega, et kõikidel esimestel verbikonstruktsioonidel on üks või

\footnotetext{
${ }^{1}$ Samas leiavad autorid, et verb tegema (ingl keeles do) ei esine mitte sugugi sama sageli laste enda kõnes ja et põhjuseks võib olla kõnealuse verbi liiga suur abstraktsuse aste.
} 
enam keskset struktuuri, mis on enamasti tugiverbikonstruktsioonid (näiteks daativiga on keskseks konstruktsiooniks peetud verbi 'andma' konstruktsioone), ja et lapsed alustavad verbikonstruktsioonide omandamist just tugiverbikonstruktsioonidest, mis on lihtsamad ja mis seega domineerivad omandamise algusfaasis. Tema arvates on leksikaalselt tühjad verbid (Tomasello kasutab terminit light verbs) ka omandamise algusfaasis kasutusel väga eri kontekstides ja mitte alati ei ole tegemist tugiverbiga. Tomasello väitel on transitiivsetes konstruktsioonides kohe algusest peale lapsel kasutusel mitu eri verbi umbes sama sagedusega ja et omandamise kontekstis ei saa rääkida ühest kindlast kesksest verbist (Tomasello 2003: 121-122).

Intransitiivsete verbide omandamist vaadelnud Anat Ninio väitel ei saa aga keeleomandamise algusetapi puhul rääkida puhtalt leksika või puhtalt reeglite õppimisest, vaid et loomuliku keele statistiline struktuur teeb võimalikuks selle, et omandamine on selles keelelise arengu järgus ühtaegu nii leksika kui ka reeglite loomise õppimine. Mingi kindla keelesüsteemi osa omandamine algab sellistest üksustest, mis on selle süsteemi n-ö parimad esindajad - kõige sagedasemad, seega ka üldisemad, prototüüpsemad, kesksemad ning kõige lihtsamad elemendid. Selliste esimeste väga üldiste elementide abil omandatakse mingid kindlad lausemallid, näiteks algab inglise ja heebrea keeles transitiivsete lausemallide omandamine mõnest n-ö mudelist, milles esinevad kõige sagedamini verbid tähendusega 'tahtma', 'tegema', 'saama', 'andma' või 'võtma'. (Ninio 1999: 112-113)

Siinse artikli alusmaterjaliks on valitud tegema-verb eelkõige seetõttu, et kuigi see paikneb kõikide verbide hulgas sageduselt kuuendal kohal, on Muischnek (2005: 17) „Eesti keele sagedussõnastiku", püsiühendite andmebaasi, tuumverbide loendi andmeid ja verbide polüseemsust arvestades leidnud, et tegema on kõige sagedamini verbikeskseid püsiühendeid moodustav verb, see kuulub eesti keele tuumverbide hulka tänu oma üldmõistelisusele, grammatilisele funktsioonile ja suurele sagedusele. Lisaks omandatakse tegema-verb ühena esimestest verbidest (Tragel 2003: 157 ja Argus 2004: 46).

Siinse kirjutise üldine eesmärk ongi vaadelda, kuidas tegemaverbi ühendite kasutus vanema kõnes lapse kasvades muutub 
ning milline roll on üldse tegema-verbil lapsele suunatud kõnes. Kuna Kadri Muischneki andmetel on 30\% verbi tegema kasutustest ajakirjanduskorpuses tugiverbilised (Muischnek 2005: 17), keskendutakse järgnevas analüüsis esmalt tegema-verbile kui tugiverbile ning vaadeldakse, kui suur hulk tegema-verbi konstruktsioonidest lapsele suunatud kõnes on tugiverbilised ning kas nende konstruktsioonide hulk lapse kasvades muutub.

Muischneki väitel on tegema tugiverbina selline verb, mis ei kombineeru noomenitega nii vabalt kui teised tugiverbid ning suurem osa tegema-verbi konstruktsioonidest on püsiühendid (Muischnek 2005: 17). Seega võimaldab just selle verbi analüüs demonstreerida, kui suure hulga tugiverbikonstruktsioonidest moodustavad lapsele suunatud kõnes püsiühendid ehk kui palju võib olla selliseid malle, mille laps saab täiskasvanu kõnest n-ö tervikuna kätte ja ka omandab tervikuna.

Muischneki andmetel aitab tugiverbi kasutamine tuua lauses esile tähendusnüansse, mida täistähendusliku verbiga on raskem väljendada, näiteks muidu intransitiivse verbi ja objekti ühendi kasutamisel saab väljendada perfektiivsust või imperfektiivsust (Muischnek 2005: 34). Sellest lähtuvalt on ka siin vaatluse all, kuivõrd on lapsele suunatud kõnes kasutatud tegema-verbi selleks, et väljendada lihtsalt tegevust (nt tegi kükke) või on sagedamini selle verbiga väljendatud tegevusel ka tulemus (tegi pissi püksi), teisisõnu: kas lapsele suunatud kõne puhul võib tegemaverbi kasutamise olulisim eesmärk olla aspektilisuse väljendamine.

Kuna tegema-verb on eriti just tugiverbikonstruktsioonides leksikaalselt tühjenenud ega mängi olulist rolli leksika omandamises, võib selle verbi olulisus seisneda hoopis grammatika omandamises. Kui tegema-verb aitab lapsel muutemorfoloogiat omandada, peaks just selle verbi vormistik olema nii hoidja- kui ka lapsekeeles võrreldes teiste verbide vormide hulgaga oluliselt suurem. On leitud, et morfo(fono)loogiliste mallide omadused, nagu läbipaistvus ja sagedus, mängivad morfoloogilise süsteemi arengus väga olulist rolli (Bittner jt 2003: XVIII), mis tähendab, et laps valib teatud kontekstist teatud vorme, mis on sagedasemad ja läbipaistvad. Samad tegurid võivad olla olulised ka morfosüntaktiliste mallide omandamisel ning seetõttu on ka alljärg- 
nevas vaatluses nii tegema-verbi tugiverbilise olemuse kui ka püsiühendites esinemise juures peatutud nende kahe teguri võimalikul mõjul.

\section{Tegema-verbi hulk keelematerjalis}

Siinse analüüsi alusmaterjalina on kasutatud spontaanse kõne lindistusi (Hendriku korpus CHILDESis ${ }^{2}$ ) lapse vanusest 1;82;5, kokku 205 minutit. Kuigi analüüsitud on nii lapsele suunatud kõne kui ka lapse enda kõne, on vaatluskeskmes siiski just esimene.

Hoidjakeeles esineb tegema-verbi kõikides lindistustes kokku 219 korral. Sageduselt jääb tegema-verb hoidjakeeles olemaverbi järel teisele, lapse keelekasutuses aga alles viiendale kohale (vt tabel 1).

Tabel 1. Verbide sagedusjärjestus (arvestatuna esinemisjuhtudes)

\begin{tabular}{l|l}
\hline Lapsele suunatud kõne & Lapse kõne \\
\hline 1) olema $(224)$ & 1) olema $(84)$ \\
2) tegema $(219)$ & 2) panema $(34)$ \\
3) panema $(168)$ & 3) minema (21) \\
4) saama $(83)$ & 4) saama $(15)$ \\
5) minema $(50)$ & 5) tegema $(11)$
\end{tabular}

Seega on selgelt näha, et verbil tegema on oluline roll just lapsele suunatud kõnes. Esitatud sagedusjärjestus annab tuge Sethuraman ja Goodmani (2004: 63) väitele, et tegema-verbi kasutuses on lapse ja lapsevanema kõne puhul märgata teatav asümmeetria ning laste kõnes on see verb väiksema kasutussagedusega.

Joonis 1 annab ülevaate tegema-verbi konstruktsioonide esinemissagedusest ja selle muutumisest lapsele suunatud kõnes ning sellelt võib näha, et tegema-verbi sagedus hoidjakeeles on

${ }^{2}$ http://childes.psy.cmu.edu/ (8.04.2010) 
dialoogiti üksjagu erinev ${ }^{3}$ : esinemisjuhtude hulk ulatub 5\%-st kuni 20\%-ni kõikidest verbisõnedest (viimasel juhul kokku 15 tegema-verbi kasutusjuhtu tunniajalises lindistuses). Kõige rohkem esines tegema-verb ühes dialoogis ema kõnes 33 korral, lapse vanuses 2;2.16. Lapse vanuse kasvades tegema-verbi kasutusjuhtude arv hoidjakeeles mõnevõrra väheneb ${ }^{4}$ ning alates vanusest 2;2 enam üle 15\% ei tõuse.

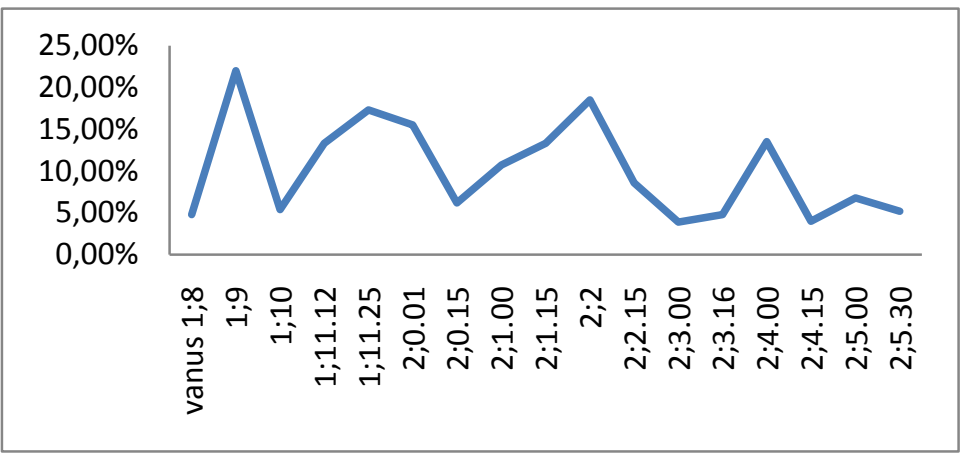

Joonis 1. Tegema-verbi osakaal kõikide verbisõnede hulgas lapsele suunatud kõnes.

Lapse varases kõnes tegema-verbi (ega ka teisi verbe) enne kaheaastaseks saamist esialgu ei esine (vt joonis 2) ning esimene tegema-verbi kasutus on registreeritud lapse kõnes vanuses $2 ; 1$. Sarnaselt lapsele suunatud kõnega ilmneb ka lapse kõne andmetest dialoogiti tegema-verbi väga erinev kasutussagedus näiteks vanuses 2;1.15 lindistatud dialoogis moodustas üle $40 \%$ kõikidest verbisõnedest tegema-verb (vt joonis 2).

\footnotetext{
${ }^{3}$ Tegema-verbi sagedus jääb tunduvalt alla olema-verbi sagedusele, samas kuulub see verb viie sagedasema verbi hulka.

${ }^{4}$ Tegema-verbi kasutusjuhtude arv ühes lindistuses on märkimisväärne veel seetõttu, et vaatlusperioodi lõpu lindistused on kestuselt pikemad kui vaatlusperioodi alguse lindistused.
} 


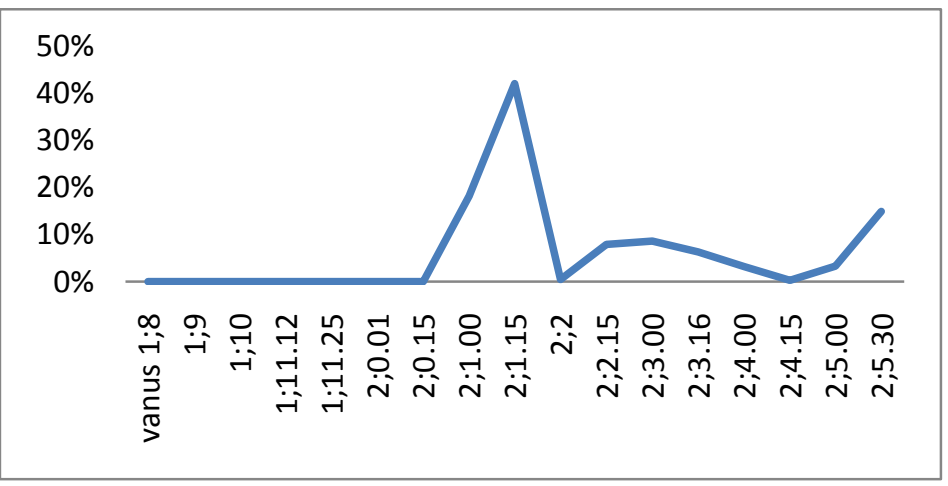

Joonis 2. Tegema-verbi osakaal kõikide verbisõnede hulgas lapse kõnes.

Samas, kui arvestada aga seda, et selles vanuses lindistatud dialoogis leidus üldse kokku seitse verbisõnet ning neist kolme puhul oli tegemist tegema-verbiga, ei saa vastavaid andmeid kuigi ülevaatlikuks pidada ning väita saabki ainult seda, et kõnealuse verbi kasutussagedus lapse kasvades suureneb.

\section{Tegema kui tugiverb}

Tugiverbikonstruktsiooniks on eesti uurimustes laiemalt nimetatud verbi ja noomeni ühendit, mille tähenduse annab noomen(ifraas) ja verbi ülesanne on vormistada grammatilisi kategooriaid, nagu aeg, isik, tegumood jne. Tugiverbi noomeni kohta on öeldud, et see väljendab sündmust (tegevust, tegu, protsessi või juhtumit). Enamasti on tugiverbikonstruktsioone käsitletud süntaktilisest vaatenurgast (vt nt Muischnek 2005: 11-12).

Siinses analüüsis on tugiverbiühendit mõistetud laiemalt ning lähtutud pigem semantilistest teguritest ning seetõttu tugiverbikonstruktsioonide hulka arvatud kõik tegema-verbi ühendid, kus tegema on semantiliselt tühjenenud ning kus kogu ühendit oleks võimalik ühe verbiga asendada (näiteks teeb kaak-kaak> kaagutab, teeb mustaks > määrib). Seega kuuluvad siinses ana- 
lüüsis tugiverbikonstruktsioonide hulka ka tegema-verbi ja adverbi ühendid, nagu tegi katki, tegi lahti, mis tavaliselt määratletakse lihtsalt ühendverbidena, ning verbi ja adjektiivi ühendid, nagu tegi mustaks 'määris'. Tugiverbilisteks konstruktsioonideks ei ole peetud neid tegema-verbi kasutusjuhtumeid, mille puhul ühe verbiga asendamine ei ole võimalik (nt mis teed?, midagi ei ole teha, mis me teeme? jt).

Analüüsitud materjalist nähtub, et lapsele suunatud kõnes on tugiverbilisi tegema-verbi ühendeid lapse vanuses $1 ; 8-2 ; 5$ pisut vähem kui mittetugiverbilisi, kusjuures mõlemat tüüpi ühendite hulk jääb tavaliselt tunniajases lindistuses 8-10 esinemiskorra piiresse. Mõnes dialoogis, kus esineb mittetugiverbilisi tegemaverbi ühendeid rohkem, domineerivad sellised, kus verbi tegema on kasutatud joonistama-verbi asemel justkui omamoodi proverbina $^{5}$ (teeme 'joonistame' onule mütsi pähe lapse vanuses $1 ; 8$; teeme muru 'niidame muru' lapse vanuses $2 ; 4$ ). Selliseid proverbilaadseid kasutusi on kogu tegema-verbi konstruktsioonidest pea kolmandik (33\%). Ülejäänud kordadel kasutab vanem oma kõnes tegema-verbi abstraktsemas ja rutiinses tähenduses, küsides kõige sagedamini lihtsalt Mis teed? või Mis me nü̈̈d teeme?, Kas nii tehaksegi? Üsna sarnased andmed tegema-verbi kõige sagedasemate kasutusviiside kohta lapsele suunatud kõnes on saanud ka Sethuraman ja Goodman (2004: 62) .

Dialoogiti võib tegema tugiverbiliste kasutuste hulk tugevalt varieeruda: on neid dialooge, kus pea kõik tegema-verbid on kasutusel tugiverbina, aga on ka neid, kus tugiverbiliste konstruktsioonide hulk on ainult $20 \%$ piires. Kui arvata kokku kõik siinse artikli aluseks olevad dialoogid, siis selgub, et tegema-verb esineb tugiverbina lastele suunatud kõnes siiski suurema sagedusega kui näiteks Kadri Muischneki (2005: 17) analüüsitud ajakirjanduskorpuse materjalis - lapsele suunatud kõnes oli 45\% tegema-verbi sisaldavatest konstruktsioonidest selliseid, kus tegema esines tugiverbina (ajakirjanduskorpuses oli tugiverbilisi ühendeid 30\%). Lapse vanuse kasvades tugiverbiliste tegemaverbi ühendite osakaal kõikide tegema-verbi kasutuste hulgas

${ }^{5}$ Termini kohta vt Muischnek 2006a: 8 või Tragel 2003: 45. 
oluliselt ei muutu, kuigi dialoogiti on see erinev, ja jääb lapse vanuses 2;5 ligikaudu $40 \%$ piiresse.

Tugiverbilised tegema-verbi ühendid võib omakorda jaotada kolmeks. Kõige suurema hulga, ligikaudu poole, moodustavad tegema-verbi ja mõne onomatopoeetilise sõna ühendid, nagu kägu ei tee kaak-kaak, (auto) teeb tuut-tuut, teeb kõmm, teete sulla-sulla, tegi viu-viu jts. Selliste ühendite kasutuse taga võib näha püüdu hõlbustada nii tähenduse (häälitsus on ikoonilisem ja kergemini objektiga seostav kui teised sõnad) ${ }^{6}$ kui ka muutemorfoloogia omandamist: tegema-verbi ühendist on kergem eri vorme moodustada kui vastavast tuletisest, nt on ühendi teeb tuut-tuut puhul vaja muuta ainult tegema-verbi, mille muutevormid on juba varakult ja enamasti tervikuna omandatud, tuletise tuututab puhul tuleb lapsel ära õppida kogu vormistik. Kõik eelmainitud onomatopoeetilised sõnad on lapse kõnes olemas juba enne kaheaastaseks saamist ning võib oletada, et ema püüabki kasutada just neid sõnu, mis on lapsel juba omandatud. Seega on selliste ühendite sagedase kasutamise üheks võimalikuks põhjuseks vanema püüd pakkuda lapsele omandamiseks tavalisest verbist tunduvalt läbipaistvam ja tuttavatest elementidest koosnev ühend.

Nii nagu on mõnel juhul raske määratleda, kas tegemist on onomatopoeetilise sõnaga või lihtsalt reduplikatiiviga (vt nt Argus 2005), on siinseski materjalis rohkem või vähem onomatopoeetilisi ühendeid, näiteks eelmainitute kõrval ka reduplikatiive, nagu tegi ai-ai või tegi mämm-mämm, mille puhul on helijäljendus küsitav. Selge on aga siiski selliste ühendite sarnane roll omandamise käigus: tegemist on tegema-verbi sagedase (ja ilmselt juba mõne omandatud muutevormi) ja mutumatute ja varem omandatud reduplikatiivide ühenditega, mida paistab lapsel olevat kergem kasutada kui vastavaid verbe. Võrreldagu siinkohal näiteks kas või sagedast hoidjakeelset ühendit tegi mämm-mämm, kus muutub ainult tegema-verb, ja verbi sööma, mille puhul tuleb omandada ka tüvevaheldus. Nii onomatopoee-

${ }^{6} \mathrm{Ka}$ teiste keelte omandamise alastest uuringutest on selgunud, et lapsed õpivad onomatopoeetilisi verbe tunduvalt hõlpsamini kui tavalisi (Mutsumi jt 2008: 54). 
tiliste sõnade kui ka lihtsalt reduplikatiivide ja tegema-verbi ühendite puhul võib väita, et need on väga tunnuslikud just hoidjakeelele ja täiskasvanuile suunatud kõnes sedalaadi ühendeid üldjuhul ei esine.

Ülejäänud tugiverbiühendid jaotuvad kaheks: tegema-verbi ning määr- või omadussõna ühendid, nagu tegi katki, tegi lahti, tühjaks teed, tegi puhtaks, tegi mustaks, ning tegema-verbi ja noomeni ühendid, nagu tegi pissi püksi, teeb haiget, pai teed, tegi häält. Ka viimasesse rühma liigituvad mõningad reduplikatiivid, näiteks tegi häbi-häbi, tegi pai-pai.

On arvatud, et varase keeleomandamise perioodil keskenduvad lapsed pigem sündmusetüübile kui verbi semantilisele sisule ning et viimaste puhul on oluline väljendada hästi selgelt teelisust. Schulz jt (2001: 409) väidavad, et saksa keeles võimaldavad verbid tähendusega 'lahti tegema', 'kinni panema' väljendada teelisust eksplitsiitsemalt kui lihtverbid. Muischneki sõnul võimaldab erinevate tugiverbikonstruktsioonide kasutamine esitada sama sündmust eri vaatepunktidest ja asetada esiplaanile sama sündmuse eri osalisi (Muischnek 2005: 34). Eelkirjeldatud esimest tüüpi ehk adverbi või adjektiivi ning tegema-verbi konstruktsioonid võimaldavadki tuua esile tegevuse jaotumise ajas: adverbiga saab rõhutada sündmuse-tegevuse teelisust, nt ühendite tegi katki, teed lahti, tühjaks teed koosseisus on erinevalt lihtverbidest protsessi lõpp-punkt juba eksplitseeritud. Laps aga ei tajugi sageli tegema ja adverbi ühendites tegema-verbi kui leksikaalset üksust, selle tähendus ei ole ka kommunikatsiooni seisukohast oluline, ning ta võib jätta selle üksuse üldse lausest välja:

*CHI: mina ikka kapoti selle lahti

*CHI: uks selle tahti [: lahti] (lapse vanus 2;6).

Keeleomandamiskirjandusest võib leida viiteid selle kohta, et lastel on raskem omandada just verbide tähendusi, kuna verbid ei ole nii konkreetsed kui objektid, mis on lisaks tähenduse paremale piiritletavusele ruumis ka ajas paremini jälgitavad. Näiteks ongi väidetud, et kuna keeleomandamine toimub jagatud tähelepanu situatsioonis (vt mõiste kohta Tomasello 2003: 3), on 
objekte kergem omandada kui verbe sellepärast, et objektidele on kergem oma jagatud (visuaalset) tähelepanu suunata (Schulz jt 2001: 407). Lisaks on võimalik noomeni ja verbi ühendi kasutamisel asetada tähelepanu keskmesse sündmuse eri vaatepunkte, eesti keeles on võimalik objekti ja verbi ühendiga väljendada veelgi konkreetsemalt tegevuse perfektiivsust kui lihtverbiga. Näiteks ühend tegi pissi püksi asetab tähelepanu keskmesse tegevuse tulemuse. Samuti nagu adverbi või adjektiivi ja tegema-verbi ühendites, kasutab laps neid sageli hoopis nii, et jätab tegema kui leksikaalselt tühja elemendi lausungist välja:

*CHI: Ninnu süüa ei.

*EMA: Ninnu süüa ei tee? (lapse vanus 2;1)

Mõnede noomeni ja tegema-verbide ühendite puhul ei ole aga ilmselgelt tähelepanu keskmes tegevuse perfektiivsus: näiteks ühendite tegid pai või teeb haiget puhul ei ole tegevuse lõpptulemus, näiteks pai, pärast tegevuse lõppu vaadeldav. Nende ühendite puhul on aga tegemist sagedaste püsiühenditega.

Kuna kõikidest tegema-verbi ühenditest moodustavad objekti ja tegema ühendid kolmandiku ning neist omakorda perfektiivsust rõhutavad ühendid umbes poole, ei saa kindlalt väita, et tegema-verbi ja noomeni või adverbi ühendite puhul oleks kõige olulisem roll perfektiivsuse selgemate väljendusvõimaluste kasutamisega. Pigem paistab, tegemist olevat nii semantiliselt, leksikaalselt kui ka morfoloogiliselt läbipaistvama konstruktsiooni eelistamisega.

Tugiverbikonstruktsioonide olemus hoidjakeeles muutub mõnevõrra vastavalt lapse vanusele. Vaatlusperioodi alguses, vanuses aasta ja kaheksa kuni üksteist kuud domineerivad hoidjakeeles onomatopoeetiliste sõnade ja tegema-verbi ühendid. Adverbi või adjektiivi ja tegema-verbi ühendeid on sel perioodil hoidjakeeles vaid üksikuid, kuid nende hulk suureneb märgatavalt alates lapse vanusest $1 ; 11$. Ka noomeni ja tegema-verbi ühendite hulk kasvab vanuses $1 ; 11$ ning jääb üldjoontes samaks kogu vaatlusperioodi jooksul (kaks kuni neli eri ühendit igas lindistuses). Onomatopoeetiliste sõnade ja tegema-verbi ühendite hulk tasapisi hoidjakeeles väheneb ning kui vaatlusperioodi al- 
guses oli neid 4-6, siis vaatlusperioodi lõpus 1-2 igas lindistuses.

Vaadeldes tegema-verbi ühendeid lapse kõnes, võib märgata, et vaatlusperioodi alguses kuni vanuseni $2 ; 2$ kasutab laps tegema-verbi ainult tugiverbina, nt sü̈̈a ei tee, katki tegi, kuid alates vanusest 2;3 hakkab suurenema selliste tegema-verbi kasutuste hulk, kus tegemist ei ole tugiverbikonstruktsiooniga ning vaatlusperioodi lõpus on tugiverbilisi tegema-verbi kasutusi umbes sama palju kui teisi. Päris rutiinväljendeid, nagu Mis teed? lapse kõnes siiski ei esine, ja seda ilmselt lapse ja täiskasvanu vahelise vestluse eripärast tulenevalt.

\section{Tegema-verb püsiühendeis}

Püsiühendina on käsitletud kahe või enama sõna(vormi) ühendeid, mida on mingi tähenduse väljendamiseks tavaks koos kasutada. Need on keelendid, mida inimese mälus arvatavasti talletatakse tervikuna (Muischnek 2006: 12). Püsiühendi puhul on tegemist kollokatsiooniga, kus tervikut on võimalik mõista osade tavatähenduse kaudu, kuid ühendit kasutatakse mingi tavapärase olukorra kirjeldamiseks, nad on rutiniseerunud (vt Muischnek 2006: 17).

Paljud keeleomandamise uurijad on arutlenud selle üle, kui suur osa keelesüsteemist omandatakse terviküksustena ning kui suurt osa mängib süsteemiloome. Vihmani järgi võib tervikutena omandamine esimese ja teise keele puhul olla eri määral rakendatud, st et esimese keele omandamisel ei ole terviküksustena omandamine sugugi nii valdav kui just teise keele omandamisel (Vihman 1982: 267). Seetõttu ongi siinkohal oluline vaadelda ka seda, kui palju on lapsele suunatud kõnes neid ühendeid, mis oleks potentsiaalselt lapsele kättesaadavad tervikuna. Kontrollides siinses analüüsmaterjalis esinenud tegema-verbi ühendite esinemist eesti keele püsiühendite andmebaasis ${ }^{7}$, selgus, et $17 \%$ 1 juhtudest esines tegema-verb hoidjakeeles mingi püsiühendi

${ }^{7}$ (http://www.cl.ut.ee/ressursid/pysiyhendid/kasutajaliides?query=) (09.04.2010) 
koosseisus. Kõige sagedasemad sellised ühendid olid katki tegema, lahti tegema ja pai tegema.

Suurel määral rutiniseerunuks võib lugeda ka sellised väljendid nagu Mis teed? Nii ei tehta! ja Midagi pole teha, mis on samuti hoidjakeeles väga sagedased ja moodustavad kogu lapsele suunatud tegema-verbi ühenditest $31 \%$. Seega võib väita, et rutiniseerunud mallid ja püsiühendid kokku ehk konstruktsioonid, mille saab laps põhimõtteliselt omandada tervikuna, moodustavad lapsele suunatud kõnes esinevatest tegema-verbi ühenditest peaaegu poole.

Võrdluseks olgu mainitud, et lapse enda kõnes eelmainitud rutiniseerunud tegema-verbi ühendeid ei leidu. Võib arvata, et hoolimata sellest, et lapsega kõnelev täiskasvanu sedalaadi ühendeid sageli kasutab, valib laps keelevahenditest ikkagi sellise, mida tal endal konkreetses kõneolukorras vaja läheb ning kuna varasel keeleomandamise perioodil juhib lapse ja täiskasvanu vahelist vestlust enamasti täiskasvanu (sageli lausungitega, nagu Mis teed? Nii ei tehta!), ei olegi lapsel endal sedalaadi ühendeid vaja kasutada.

\section{Tegema-verbi vormimoodustus}

Vaadeldes tegema-verbi vormimoodustust, selgub, et hoidjakeel pakub lapsele just nimelt sellest verbist kõige ulatuslikuma muuteparadigma: tegema-verbist esineb pea igas lindistuses kõige suurem hulk eri vorme. Tegema ei ole küll esimene verb, millest laps miniparadigma moodustab ${ }^{8}$. Varem tekivad lapse keelekasutusse olema- ja panema-verbi miniparadigmad ning tegema-verbist tekib esimene miniparadigma alles pärast eelesitatud kaht verbi. Samas on aga perioodil, mil lapse kõnes esineb pea igast verbist ainult üks vorm, tegema-verb igas lindistuses esindatud alati vähemalt kahe vormi vastandustega.

Kõnealuse verbi paradigma on hoidjakeeles esindatud kõige vähem kolme eri vormiga ühes dialoogis, aga kõige enam lausa 13 eri vormiga lapse vanuses $2 ; 2$. Alates vanusest $2 ; 3$ jääb te-

${ }^{8}$ Miniparadigma mõiste kohta vt Argus 2008. 
gema-verbi miniparadigmade suurus siiski tasapisi väiksemaks ja lindistustest võib leida keskmiselt 7-8 eri vormi. Võrreldes tegema-verbi vormide hulka hoidjakeeles teiste verbide omaga, selgub, et nii ulatuslikku paradigmat ühestki teisest verbist hoidjakeeles ei ole. Tegema-verbile järgnevad paradigma suuruselt olema-verb kõige rohkem kuue eri vormiga ühes lindistuses ning panema ja minema 5-6 eri vormiga. Lapse kasvades suureneb teiste verbide vormivalik: kui näiteks lapse vanuses $1 ; 10$ esines lapsele suunatud kõnes ainult kolmest verbist rohkem kui kaks eri vormi, siis lapse vanuses $2 ; 5$ on rohkem kui kolme vormiga esindatud 6 verbi.

Hoidjakeele verbide vormivalikut vaadeldes on ilmne, et mingil keelelise arengu perioodil (siinse materjali puhul võib oletada, et lapse kaheaastaseks saamise ajal) pakub vanem lapsele sellist keelevarianti, kus domineerib üks kindel ja ka fonoloogiliselt lihtne verb oma paljude vormidega. Lapse kasvades jääb kõnealuse verbi vormistik tasapisi väiksemaks ning suureneb teiste verbide vormihulk.

\section{Kokkuvõtvalt tegema-verbi rollist hoidjakeeles}

Analüüsitud keelematerjal näitas, et verbil tegema on eesti keele omandamise kontekstis oluline roll. Et tegema-verb on lapsele suunatud kõnes võrreldes teiste verbidega väga sage ning lapse kasvades selle verbi ühendite sagedus mõnevõrra väheneb ning ka laad mõnevõrra muutub, on alust oletada, et ka eesti keeles on selle verbi puhul tegemist sellise verbiga, mis on oluline just nimelt omandamise kontekstis ning täpsemalt keeleomandamise varasel perioodil.

Kuigi vaadeldud materjal andis toetust ka Michael Tomasello väitele, et leksikaalselt tühjad verbid võivad olla kasutusel erinevates konstruktsioonides ning sugugi mitte alati ei esine nad tugiverbidena, leidus ometi lapsele suunatud kõnes tegema-verbi tugiverbilisi kasutusi tunduvalt rohkem kui Muischneki analüüsitud ajakirjanduskorpuses. See, kas tegema-verbi sagedasem tugiverbina kasutamine on iseloomulik üldse suulisele kõnele, 
seal hulgas lapsele suunatud kõnele, vajab veel edasist selgitamist.

Kuigi tugiverbikonstruktsioonide hulgas leidus palju ühendeid, kus tegema-verbi konstruktsioon võimaldas tuua esile kas tegevuse jaotumise ajas ehk rõhutada sündmuse-tegevuse teelisust või perfektiivsust, ei saa siiski väita, et tegema-verbi ühendite puhul oleks enamasti tegemist aspektilisuse selgema väljendusvõimaluse otsimisega, pigem annab suur hulk onomatopoeetiliste ja reduplikatiivsete sõnade ühendeid alust oletada, et lapsega rääkides eelistatakse nii semantiliselt kui ka morfoloogiliselt võimalikult läbipaistvat, lihtsamat ja üldisemat väljendusviisi.

Rutiniseerunud mallid ja püsiühendid ehk konstruktsioonid, mille saab laps täiskasvanu kõnest jagamata tervikuna, moodustavad lapsele suunatud kõnes esinevatest tegema-verbi ühenditest peaaegu poole ning kuigi laps ise sedalaadi malle kuigivõrd ei kasuta, suurendavad need ometi tegema-verbi eri vormide üldist sagedust hoidjakeeles. Just kõnealuse verbi vormisagedus osutab sellele, et tegema on oluline nimelt muutemorfoloogia omandamise kontekstis: selle verbi vormistik on hoidjakeeles teiste verbide omast tunduvalt laiem. Seega aitab hoidjakeelele omane tegema-verbi ühendite sage kasutamine lapsel omandada ka muutemorfoloogiat. Kõnealuse verbi ühendite eelistamise puhul ilmneb omandamistegurite - sageduse ja läbipaistvuse mõju: vanem valib lapsega suheldes sagedase, üldise ja keskse tegema-verbiga konstruktsiooni, mis on lapse jaoks sageli läbipaistvam kui lihtverb.

Reili Argus

Ugala 25

11613 Tallinn

reili.argus@tlu.ee

\section{Kirjandus}

Argus, Reili (2004) „Eesti keele käändesüsteemi omandamine: esimestest sõnadest miniparadigmadeni“". Emakeele Seltsi aastaraamat 49 (2003), 23-48.Tallinn: Emakeele Selts. 
Argus, Reili (2005) „Imitatiivide kohast lapsekeeles: reduplikatsioonist, morfoloogiast ja sõnaliigilisest ambivalentsusest"“. Margit Langemets, koost., Maria-Maren Sepper, toim. Eesti Rakenduslingvistika Ühingu aastaraamat 1 (2004), 19-34.Tallinn: Eesti Keele Sihtasutus.

Argus, Reili (2008) Eesti keele muutemorfoloogia omandamine. (Tallinna ülikooli humanitaarteaduste dissertatsioonid 19.) Tallinn: TLÜ Kirjastus.

Bittner jt 2003 = Bittner, Dagmar, Wolfgang U. Dressler, Marianne Kilani-Schoch, toim. (2003) Development of verb inflection in first language acquisition. A cross-linguistic perspective. (Studies on Language Acquisition 21.) Berlin/New York: Mouton de Gruyter.

Brown, Roger (1973) A first language: The early stages. Cambridge, Mass.: Harvard University Press.

Cameron-Faulkner jt 2003 = Cameron-Faulkner, Thea, Elena Lieven, Michael Tomasello (2003) "A construction based analysis of child directed speech". Cognitive Science 27, 843-873.

Goldberg jt 2004 = Goldberg, Adele E., Devin Casenhiser, Nitya Sethuraman (2004) "Learning argument structure generalizations". Cognitive Linguistics 15, 3, 289-316.

Lieven jt 1997 = Lieven, Elena V. M., Julia Pine, Gillian Baldwin (1997) "Lexically-based learning and the development of grammar in early multi-word speech". Journal of Child Language 24, 1, 187-219.

Muischnek, Kadri (2005) „Eesti keele tugiverbid ja nende mõju lause ehitusele“. Emakeele Seltsi aastaraamat 50 (2004), 11-38. Tallinn.

Muischnek, Kadri (2006) Verbi ja noomeni püsiühendid eesti keeles. (Dissertationes philologiae estonicae universitatis tartuensis 17.) Tartu: Tartu Ülikooli Kirjastus.

Mutsumi jt 2008 = Mutsumi Imai, Sotaro Kita, Miho Nagumo, Hiroyuki Okada (2008) "Sound symbolism facilitates early verb learning". Cognition, vol. 109, 1, 54-65.

Ninio, Anat (1999) "Model learning in syntactic development: Intransitive verbs". International Journal of Bilingualism 3, 111-131.

Schulz jt 2001 = Schulz, Petra, Karin Wymann, Zvy Penner (2001) "The early acquisition of verb meaning in German by normally developing and language impaired children". Brain and Language 77, 407-418.

Sethuraman, Nitya, Judith C. Goodman (2004) "Children's mastery of the transitive construction". Proceedings of the 32nd Stanford Child Language Research Forum, 60-67. 
Theakston jt 2001 = Theakston, Anna L., Elena Lieven, Julian M. Pine, Caroline F. Rowland (2001) "The role of performance limitations in the acquisition of verb-argument structure: an alternative account". Journal of Child Language 28, 127-152.

Tomasello, Michael (2003) Constructing a language. A usage-based theory of language acquisition. Cambridge: Harvard University Press.

Tragel, Ilona (2003) Eesti keele tuumverbid. (Dissertationes linguisticae universitatis tartuensis 3.) Tartu: Tartu Ülikooli Kirjastus.

Vihman, Marilyn May (1982) "Formulas in first and second language acquisition". L. K. Obler, L. Menn, toim. Exceptional language and linguistics. Perspectives in neurolinguistics, neuropsychology, and psycholinguistics, 261-284. New York: Academic Press.

Reili Argus: Constructions with the Verb tegema 'do, make' in Child Directed Speech. The child directed speech has a great impact on the child language development and offers to the child the statistical structure of natural language, where the most salient position is held by a most frequent, general, prototypical, central and less complex element of a language to be acquired. The verb tegema 'do/make' is one of the most frequent verbs in child directed speech in Estonian. The amount and structure of different constructions with the verb tegema change as the child's language develops. Light verb constructions with the verb tegema can be divided into three main groups: the verb tegema with some onomatopoetic word, with an adjective or an adverb and with a noun, while the most sizeable group is the one with onomatopoetic words. Concerning the big amount of formulaic expressions and routines with the verb tegema it can be assumed that some kind of ready-made chunks of language are preferred to be used in the child directed speech. Although the verb tegema has a role in the acquisition of lexicon and syntax, its most prominent role can be that of facilitating the acquisition of inflectional morphology - the paradigm of the verb tegema is the largest one among other verbs both in child directed and the child's speech.

Keywords: first language acquisition, light verbs, child directed speech 